\title{
TAX PREFERENCES IN THE CZECH AND POLISH PERSONAL INCOME TAXES
}

\author{
Marcin Burzec*
}

\begin{abstract}
Article presents tax preferences in Czech Republic and Poland in the comparative aproach. The aim of the comparative study is to show how particular problems can be tackled by different countries by different measures. Both in Poland and the Czech Republic it is possible to identify common problems in the area of the tax law. One of such problems is an appropriate shape of tax preferences within the income tax contruction. The aim of the present article is to demonstrate how Poland and the Czech Republic, by shaping tax preferences within the construction of the income tax, tackle the problem of the taxpayer's ability to pay. Further, it is shown how the two countries, by means of tax instruments, supplement their policy in areas as important as pro-family policy, supporting subjects implementing public tasks, the pension system, policy on people with disabilities, and housing policy.
\end{abstract}

Key words: personal income tax, tax preferences, comparative tax law

\section{PRELIMINARIES}

In the literature on the subject of comparative tax law, Poland and the Czech Republic have been qualified to the group of transition and post-conflict countries ${ }^{1}$. The group is not uniform, but there is one feature

\footnotetext{
* $P h D-$ Associate Professor, Department of Finance and Finance Law, Faculty of Law, Canon Law and Administration, The John Paul II Catholic University of Lublin.

1 V. Thuronyi, Comparative Tax Law, The Hague-London-New York 2003, pp. 33 38. More about legal families see: K. Zweigert, H. Kötz, Introduction to Comparative Law, Oxford 1998, pp. 63 et seq.
} 
the countries have in common. Namely, as the result of the political and economic changes, also the law system has changed to such a degree that it is impossible to assign it to one particular family of tax law. It has to be emphasised that the common element of the Czech and Polish tax systems is the fact that for over fourty years they had remained under a strong influence of concepts originating in the Soviet Union. Moreover, due to social and economic changes taking place in the early 1990s, the reforms of tax systems in these two countries were based on the legal regulations operating in the OECD countries.

The aim of the comparative study is to show how particular problems can be tackled by different countries by different measures ${ }^{2}$. Both in Poland and the Czech Republic it is possible to identify common problems in the area of the tax law. One of such problems is an appropriate shape of tax preferences within the income tax contruction. In particular, deduction from the taxable base and tax reliefs. The main task of the tax preferences is to take into account the taxpayer's ability to pay so that the tax burden is adjusted to the taxpayer's individual abilities. Additionally, tax preferences can also fulfill stimulating functions thus complementing the country's specific policy in the area of demography or tasks performed by non-governmental organizations, or stimulating taxpayers to particular behaviours.

The aim of the present article is to demonstrate how Poland and the Czech Republic, by shaping tax preferences within the construction of the income tax ${ }^{3}$, tackle the problem of the taxpayer's ability to pay ${ }^{4}$. Further, it is shown how the two countries, by means of tax instruments, supplement their policy in areas as important as pro-family policy, supporting subjects implementing public tasks, the pension system, policy on people with disabilities, and housing policy. It has to be stressed that some tax

2 See: G. Samuel, An Introduction to Comparative Law Theory and Method, Oxford and Portland 2014, pp. 53 et seq.; V. Thuronyi, Comparative Tax Law..., p. 3.

3 In the Czech Republic the personal income tax was regulated by the Personal Income Tax Act of 20 November 1992 (Zákon ze dne 20. listopadu 1992 o daních z př́ijmů), hereinafter referred to as the Income Tax Act. In Poland, the regulation currently in force is the Personal Income Tax Act of 26 July 1991, hereinafter referred to as the Personal Income Tax Act.

$4 \quad$ Legal state of this article as per June 2017. 
preferences have been purposedly omitted as they extend formal limitations of this paper ${ }^{5}$.

\section{THE PRO-FAMILY PREFERENCES}

Tax preferences taking family factor into account play a significant role in the construction of every income tax. These preferences include joint taxation for spouses, reductions for maintenance of adult family members, children and specific expenditure, e.g. of educational character. The purpose of the pro-family tax preferences is to take into account the taxpayer's ability to pay. This concept is reflected in the assumption that the more people are dependent on the taxpayer (e.g. children, unemployed spouses, parents, or other persons with the disability status), the smaller the taxpayer's income and, consequently, the smaller ability to bear tax burden ${ }^{6}$.

Tax preferences in the form of reliefs from the taxable base or from the tax amount are important in so far as - taking into account only the amount of income with no necessity to maintain other people - the reduction of payment capacity is unnoticeable. Lack of corrective pro-family tax preferences in the income tax construction would make the income tax highly unfair and deepen inequalities within a given society. Furthermore, a skillful use of structural elements within the income tax with pro-family preferences enables the state to supplement its pro-family policy so that the demographic situation is enhanced (or at least not deteriorated).

The institution based on the pro-family tax preferences is the joint taxation of spouses or single parents. This concept origins in the assumption that a family should be treated as a single source of income and expenditure necessary for its proper functioning. In Poland, joint taxation of spouses is possible. The taxed amount is the sum of each spouse's income previously reduced by amounts decreasing the taxable base. A necessary condition is

5 For example, the paper does not cover the preferences of a compensating character included into the tax system, such as e.g. a Polish Internet use relief and a Czech relief for obligatory fiscal cash register purchases.

6 See more: H.Litwińczuk, Opodatkwoanie rodziny, Warsaw 1989; W. Wójtowicz, P. Smoleń, Podatek dochodowy od osób fizycznych-prorodzinny czy neutralny?, Warsaw 1999. 
that the marriage has lasted at least one tax year and the spouses have joint property. The tax established for both spouses is equal to double the tax established for the half of their common income. Joint taxation of sposes is beneficial in two cases. Firstly, if one of them has no income in the tax year. Secondly, if there is a substatial difference between the incomes of the spouses ${ }^{7}$. Consequently, the income of one of them exceeds tax threshold and causes the necessity for a higher tax rate. In this case, a joint taxation of spouses decreases income and a lower, $18 \%$ tax rate is applicable. Additionally, the construction of the Polish income tax contains the possibility of joint taxation of a single parent or guardian of ${ }^{8}$ : minor children, disbled children regardless of age, school children under 25 years of age if they do not receive taxable income.

The Czech Republic regulates the above matters differently. Since a proportional rate of $15 \%$ has been introduced, the Czech Republic has resigned from the institution of a joint taxation of spouses. As a consequence, however, legal regulations have been introduced allowing 24.840 Kč (955 euros) tax deduction -for a spouse living with the taxpayer in the same household provided that the spouse's income does not exceed $68.000 \mathrm{Kč}$ (2615 euros). If the spouse holds a disability certificate ZTP/P', the sum of the relief doubles and equal to 49.680 Kč (1910 euros).

An important instrument within the pro-family tax preferences is taking childcare into account. The analysis of the European states' legal regulations shows that the above-mentioned preferences may take one of the following froms:

- deductions reducing taxable income (taxable base);

7 In Poland there are two rates within the tax scale: $18 \%$ and $32 \%$, levied on the surplus of 85.528 PLN.

8 The necessary condition is for the parent or guardian to be: single, widow, widower, divorced man or woman, legally separated person, a married person whose spouse has been deprived of parental rights or is imprisoned.

9 The third grade disability certificate may be acquired by heavily mobility impaired persons and disabled persons with general mobility. The third grade of disability certificate ZTP/P may also be applied for by a person with space disorder and total disability with space disorder, including persons with an Autism Spectrum Disorder. See: Art. 34 sec. 4 Zákon č. 329/2011 Sb. o poskytování dávek osobám se zdravotním postižením a o změně souvisejících zákonů. 
- tax reduction;

- the so-called tax bonus limited by the tax amount;

- the sum of tax reduction and the so-called tax bonus.

In the present legal position in both the Czech Republic and in Poland it has been assumed that a taxpayer with children ${ }^{10}$ is entitled to tax reduction with possible application of the so-called tax bonus applied if the income tax amount is lower than the amount of allowable reliefs.

Despite assuming the same concept, however, the two countries take different approaches to the questions discussed above. The first difference refers to the amounts of possible deductions. In the Czech Republic they are twice as high as in Poland: 13.404 Kč (515 euros) for one child in the Czech Republic and 1112,04 PLN ( 261 euros) for one child in Poland; 17004 Kč ( 654 euros) for the second child in the Czech Republic and 1112,04 PLN in Poland; 20604 Kč (792 euros) for the third and every next child in the Czech Republic and in Poland -2000,04 PLN (470 euros) for the third child, and for the forth and every next child 2700 PLN (635 euros). Such a situation partly results from the fact that the difference in the per capita gross domestic product measured in purchasing power parities equals to 19 percentage points ${ }^{11}$.

Secondly, in both coutries the structure of the income tax displays efforts to take into account the taxpayer's ability to pay. In each country, however, different elements are emphasized. In Poland, reduced ability to pay has been directly connected with the income criterion and the number of children. That is to say, taxpayers with one child shall be entitled to the

10 In Poland, the relief is available to taxpayers who had parental authority; were legal guardians if the child lived with them; performed a finction of a foster family based on the judgement of a court or an agreement with a starost. The relief is payable for a minor child regardless of age if they claim care allowance or social pension; until reaching the age of 25 if learning in schools. In the Czech Republic, on the other hand, a child recognized as dependant of a taxpayer is a child who: is the taxpayer's own child; foster child; child the taxpayer cares for thus replacing parental care; child in a foster family; child of a second spouse; grandchild or second spouse's grandchild if parents have not enough income for the child's upbringing. The above-mentioned children must be minor, or of legal age if they do not claim second degree invalidity pension provided that they are educated for a future occupation; do not learn due to illness or injury; are not able to work due to long-term serious health problems.

11 The Eurostat data for 2016. 
relief if their income is not too high. The legislator assumed that the income of married taxpayers may not exceed 112.000 PLN ( 26.352 euros), and of single taxpayers the maximum income is 56.000 PLN (13.176 euros) ${ }^{12}$. It should be noted that the above limits are not applicable in the case of a single parent of a disabled child. Additionally, the relief is applicable regardless of the age of a disabled child. In the Czech Republic, the amount of the relief depends not only on the number of children but also on their health status. The relief may be doubled if the child holds a ZTP/P ${ }^{13}$ disability certificate.

Oftentimes, the taxpayer's low income prevents full deduction of the allowable preference. Therefore, both Poland and the Czech Republic introduced the so-called tax bonus in the form of a negative tax. That is, the state repays the unused part of the relief to the taxpayer. In the Czech Republic, the tax bonus is allowable up to 60.300 Kč (2319 euros) per year (provided that the difference between the tax and the relief is higher than $\left.100 \mathrm{~K}^{\check{c}}\right)^{14}$. In Poland, on the other hand, the limit is not determined in particular amounts but the difference between the relief and the tax may not exceed social security and health contributions ${ }^{15}$, which are deductible from the tax.

The main problem in Poland and the Czech Republic is the cost of pre-school childcare. The problem is important since, nowadays, only few married couples can afford for one of the spouses to remain unemployed. Therefore, this difficulty should be considered in many aspects. Firstly, the cost of nursery is a considerable burden to the family budget. These costs, together with parents' low income, may influence the parents' decision for having children until their finances have stabilized, which, consequently, negatively affects birth rate.

The costs of childcare result from the fact that, in order to save funds, one of the parents decides to stay at home. As the labour market lacks specialists, this trend plays a negative role in the economy and is harmful

12 Art. 27 sec. 2 the Personal Income Tax Act.

13 Art. 35c sec. 1 of the Income Tax Act.

14 I. Pařízková, Slevy na dani a daňové zvýhodnění, [in:] Finanční a daňové právo, (eds.) P. Jánošíková, P. Mrkývka, Plzeň 2016, p. 329.

15 In Poland, social insurance contributions payed by the taxpayer (retirement, disability, sickness and accident insurance) are deducted from the taxable base. 
for the parent for whom it is difficult to enter the labour market after long absence.

Apart from a complex system of childcare, some countries introduce into the structure of income tax regulations which allow deducting costs of childcare from the tax. Such costs may concern nursery/kindergarten fees as well as salaries for legally employed babysitters ${ }^{16}$. In this regard, the help of the Polish state is based only on extra-tax instruments such as subsidies for kindergartens and partial coverage of retirement insurance for babysitters. Nonetheless, tax preferences would be an interesting supplement for the relevant policy.

Importantly, however, on 1 January 2016 revised rules on personal income tax enetered into force according to which exempted from tax are benefits not exeeding $400 \mathrm{zl}$ a month which are not funded by the social fund, and which the taxpayer receives from the employer to cover the expenses of the childcare rendered by a day carer or kindergarten. Additionally, exemption includes a benefit granted by the employer to the worker to cover the costs of the kindergarten up to $200 \mathrm{zl}$ a month. The above mentioned exemptions are payable for each child. ${ }^{17}$ The above preferences should be assessed as a step in the right direction, although they are not free of shortcomings. Specifically, the idea that the exemption of a benefit given by the employer should be included in the structure of the personal income tax is not fully in line with the family-friendly policy. This is due to the fact that not every employer can afford, or is willing to, grant the worker such benefits. It seems, therefore, that it would make more sense to introduce additional option to deduct from the tax base the expenditure paid directly by the taxpayer to cover the costs of childcare.

A similar situation is encountered in the Czech Republic, where documented costs of placing each child in a kindergarten ${ }^{18}$ may be deducted from the tax if these costs do not exceed minimal salary. The only condi-

16 M. Burzec, Dziecko jako kryterium przyznania przyznania preferencji w podatku dochodowym wybranych państw europejskich, [in:] Preferencje podatkowe, (eds.) B. Kucia-Guściora, M. Burzec, Lublin 2013, pp. 89-91.

17 Art. 21, sec.1, point 67b of the Personal Income Tax Act.

18 According to Art. 35bb of the Czech Income Tax Act, the pre-school institution is understood as: kindergarten, acc. to the Educational Act; institution providing group childcare; pre-school childcare provided within business activity if it corresponds to the 
tion is for the child to be financially dependent on the taxpayer and live with them. In addition, this preference may be used by gradparents who have been granted parental authority.

Another vital problem connected with the pro-family policy are reliefs relating to children's education. An additional aim of these preferences is to increase the level of education, which, in turn, should positively influence economic competetiveness. In this context, tax instruments may supplement the country's educational policy. This is achieved firstly by a system of tax exemptions of academic and social scholarships granted to pupils and students. The income tax also includes regulations entitling the taxpayer to reliefs for maintaining a child who studies. The main aim of the above preference is to support families who incur costs connected with children's education. Furthermore, the preference encourages children to increase their professional qualifications by further education.

These aims are the same in Poland and the Czech Republic, although the ways to achieve them are different. In Poland, this objective is realized by the relief for minor children and for children at school until the age of 25. In the Czech Republic, in turn, the relief applies only to minor children. Therefore, in order to support educational policy with the tax instruments, another relief had to be introduced into the income tax structure. This is done by lowering the tax by the sum of $4020 \mathrm{Kč}$ ( 154 euros) for a studying child (320 Kč per month if education does not last the whole year) who is under the age of 26 . Additionally, if the child enrolled to fulltime doctoral studies, the preference applies until the age of $28^{19}$.

\section{PREFERENCES RELATING TO TRANSFERS FOR CHARITIES}

Many counties encourage their citizens to actively support different organisations realizing social tasks. For that reason, the income tax includes regulations promoting particular behaviours. In accordance with these regulations, the taxpayer may deduct from the income tax an amount of the

provisions of the Education Act or to childcare provided by an institution dedicated to group childcare.

$19 \$ 35$ ba sec. 1 letter $\mathrm{f}$ ) the Income Tax Act. 
donation to an organization performing specific tasks. Obviously, the deductible amount is limited. In the majority of countries the deductible amount granted as donation to specific subjects is proportional to the taxpayer's total income in the given tax year. Such regulations operate in Poland where the taxpayer may deduct from the taxable base the amount of the donation, but not more than $6 \%$ of the income obtained in the tax year ${ }^{20}$. It has to be noted that some countries establish also the lower limit. For example, in the Czech Republic the higher limit is $15 \%$ of the taxable base, and the lower limit is $2 \%$ of the taxable base or at least 1000 Kč (38 euros) above which it is possible to make the deduction ${ }^{21}$. Each country individually specifies aims and organizations that may be supported by a deductible donation. When comparing the legal regulations in Poland and in the Czech Republic, one may notice that in Poland the list of subjects able to get donations is unusually short. The donation may be granted to enlisted tasks ${ }^{22}$ realised by subjects with a non-profit status, to religious cult purposes, and to blood donation realised by voluntary blood donors ${ }^{23}$. Moreover, basing on the acts

20 Art. 26 sec. 1 point 9 of the Personal Income Tax Act.

21 S. Anderlová, Prímé danĕ, [in:] Daňové právo de lege lata, (ed.) P. Jánošiková, Plzeň 2014, p. 114.

22 The area of public tasks includes, among other things: social help, family support, free legal consulting; measures in support of social and occupational integration of persons at risk of social exclusion; charity; support and popularization of national tradition; support for national, ethnic and linguistic minorities; support for integration of foreigners; health protection and promotion; support for the disabled; promotion of employment and professional activity for the unemployed and persons at risk of losing job; promotion of equal rights for men and women; support for persons at the retirement age; support for economic and technical development; support for the development of local communities; science, higher education, upbringing; culture, art, national heritage protection; support and promotion of physical culture; ecology and animal protection; public order and safety; country's defences; promotion and protection of freedom, human rights and civil liberties; rescue services and people protection; promotion and protection of consumer rights; promotion and organization of volunteer work; help for the Polish community abroad; support for military veterans; promoting Poland abroad; pro-family, pro-maternity, proparenthood activity; promotion and protection of children's rights; preventing addiction and social pathologies.

23 If the taxpayer donates blood, the amount of the refund is calculated as quotient of blood litres and the multiplication of the refund amount determined by the Minister of Health. 
regulating legal churches and religious associations, unlimited deduction of donations to these subjects is possible. In the Czech Republic the area of public tasks is similar to that in Poland. However, the scope of the subjects is broader. It has to be mentioned that in Poland the personal income tax act refers to the non-profit organization $\mathrm{Act}^{24}$ according to which non-profit activity may be conducted by subjects who do not act to raise profit, who are legal persons or units without legal personality. The necessary condition is that these subjects may not fall within the financial sector or be firms, research institutes, banks or pledged assets being state or self-government legal persons. According to the Czech income tax act, donations which come under deduction from the taxable base may be granted to districts, regions, national organizational units, churches, legal religious associations, police, political parties, legal persons who organize public collections for culture, science, fire protection, youth education, animal protection, health protection, social, health, ecological and charity aims, physical culture and sport, and human rights. It appears, then, that, unlike in Poland, in the Czech Republic the list of the subjects allowed to be granted donations may belong to the public finance sector. Furthermore, Czech regulations allow the possibility to grant donations to physical persons managing schools, health centres, abandoned and stray animal protection, and endangered species protection. Such donations must be allotted to financing the above-mentioned centres. In addition, the donation may be granted to physical persons living in the Czech Republic entitled to invalidity allowance ${ }^{25}$. Free donation may be granted to buy medical equipment up to the amount not covered by health insurance or when one donates specialist equipment up to the amount not covered by the state budget.

\section{PREFERENCES RELATING TO DISABILITY}

The aim of the tax preferences concerning the degree of disability is to take into account the taxpayers's ability to pay. It has to be stressed that

24 Art. 3 sec. 2 and 3 of the Act on Public Benefit Activity and Volunteerism of 24 April 2003.

25 More: V. Pelc, Zákon o daních z př́ijmů - komentáŕ, Praha 2015, p. 329-345. 
according to the above preferences strictly specified costs incurred by the taxpayer to satisfy the needs of a disabled person may be deducted from the taxable base. Or, it is possible to deduct from the tax a relief determined by the tax act.

Deduction of costs or of a relief may be enjoyed by the taxpayer with a particular degree of disability. Additionally, in some cases, the preference may be enjoyed by a taxpayer who maintains disabled persons, e.g. a spouse, parents, grandparents, children, or siblings.

In the Czech Republic the payer of the income tax is entitled to a relief from the tax depending on the degree of the taxpayer's disability. Firstly, the relief applies to disabled persons with the first and second disability pension. The amount of this relief is equal to 2520 Kč (96 euros). Secondly, a person with the third degree of disability is entitled to a higher (double) amount of relief, i.e. $5040 \mathrm{Kcr}$ (193 euros). Thirdly, if the taxpayer holds a certificate stating the third degree of physical, sensory, or mental disability (ZTP/P), they are entitled to lower the tax by 16.140 Kč (620 euros). The reliefs listed above refer to the taxpayer. It has to be emphasised that the preferences concerning disabled persons dependant on the taxpayer are included in the reliefs discussed above in the form of a relief for the spouse, children, or in the form of a deduction from the taxable base of a donation granted to a disabled person ${ }^{26}$.

The preferences concerning the disability degree of the taxpayer or of dependant persons are also included in the Polish personal income tax. Contrary to the solutions taken in the Czech Republic, the taxpayer in Poland is entitled to deduct from the taxable base the costs of expenditure related to life support. The deductions may be enjoyed not only by the disabled taxpayer, but also if the taxpayer maintains disabled persons provided that these persons are: the taxpayer's spouse, own or foster child, a child taken for upbringing, stepson, parent, spouse's parent, sibling, stepfather, stepmother, son-in-law, daughter-in-law. In the above case, however, an income criterion has been introduced for the disabled dependant on the taxpayer. That is, they may not receive income exceeding 9.120 PLN (2.145 euros) in the tax year. The regulations of the Polish act include a list

$26 \$ 35$ ba sec. 1 letters: b) - e) the Income Tax Act. See more: V. Pelc, Zákon o daních..., p. 964-969. 
of expenditure that may be incurred by the taxpayer. The list includes the costs of, e.g.: adaptation and equipment of flats and buildings according to the needs resulting from disability; adaptation of mechanical vehicles; medication; necessary transport fees to required therapy and rehabilitation measures; fees for staying in a health resort; fees for blind persons' guards not exceeding 2.280 PLN (536 euros) in a tax year; maintenance of an assisting dog by blind and visually impaired persons not exceeding 2.280 PLN in a tax year; nurse's care at a disabled persons' home during longterm illness preventing movement; fees for the sign language interpreter; summer camps for disabled children and youth, disabled persons' children under the age of $25^{27}$. It has to be borne in mind that in the Polish income tax act the elements concerning the disability of a person dependant on the taxpayer include reliefs for the child upbringing as well as cumulative tax enabling a single parent to joint taxation.

\section{PREFERENCES RELATING TO HOUSING NEEDS}

From the point of view of the Czech and Polish taxpayers, a vital problem is satisfaction of housing needs. Firstly, security connected with flat ownership is oftentimes reflected in the decision to enlarge family, which is vital from the point of view of the state's demographic policy.

Further, the purchase of flats and construction of dwellings are incentives for residential development and have impact on economic growth. It is therefore no surprise that income tax contains tax preferences promoting certain behaviours of taxpayers in this regard. Although in Poland there are no reliefs decreasing tax or taxable base, there are circumstances when the income from the sale of real property may be exempt from taxation. Such situations occur when the taxpayer allocates the revenue from the sale of real property to so-called housing purposes ${ }^{28}$ provided that it is done not

27 Art. 26 sec. 7a of the Personal Income Tax Act.

28 Own housing purposes are, i.a.: expenses related to the purchase of a residential building or a flat; the purchase of the cooperative ownership right to a flat/residential building; the purchase of land for the construction of a residential building; construction, development or renovation of own residential building. In addition, expenses related to 
later than within two years from the end of tax year in which the sale was completed. It has to be noted that own housing purposes may be realised both in Poland and on the territories of the EU and EFTA states, and the Swiss Confederation.

Problems related to housing needs are recognized also by the Czech legislator. It has to be stressed, however, that while the core of the problem is the same as in Poland, the solutions adopted in the Czech Republic are very different. That is to say, the income tax provides that the taxpayer is entitled to deduct from the taxable base the amount of the mortgage credit interest payed in a given tax year, reduced by the sum of state aid in the form of loan subsidies. Moreover, it is possible to deduct interests from loans received from building societies and banks relating to loans from building savings or mortgage credits dedicated to financing own housing needs ${ }^{29}$. The relief may be deducted up to 320.000 Kč (12.307 euros) per year. It should be noted that a similar preference was in force in Poland from 1 January 2002 to 31 December 2006. The preference allowed to deduct from the taxable base actual expenses incurred in the tax year to pay the credit (loan) used to finance investments fulfilling own housing needs. The necessary condition was the acquisition of a new flat or house, or transformation of a non-residential building into a residential one. The mortgage interest tax deduction applied only to the interests on the part of the credit (loan) which did not exceed the limit measured as a product of $70 \mathrm{~m}^{2}$ of floor area and a $1 \mathrm{~m}^{2}$ floor area conversion factor. The conversion factor was defined on the basis of the savings on the housing savings book for the third quarter of the year preceding the tax year set for the year of the investment completion. It has to be

own housing purposes also include reimbursement of a loan or credit taken for the aforementioned purposes.

29 Own housing purposes are, i.a.: construction of a residential building or a flat, which do not include non-residential premises other than garage, cellar, chamber, or their renovation; the purchase of land provided that the construction related to the housing purposes shall begin within 4 years from the time of the purchase or the conclusion of the credit agrrement; the purchase of the first residential building; renovation of a residential building; division of jointly-held assets in the case of the dissolution of shared ownership of a married couple or heirs; reimbursement of a credit or a loan used for financing the housing needs. 
stressed that the deduction still applies to those taxpayers who concluded a mortgage loan contract before 1 January 2007, but this is possible only until 31 December 2027.

\section{PREFERENCES RELATING TO SUPPLEMENTATION OF THE PENSION SCHEME}

Continuing low birth rate in Poland and in the Czech Republic may result, in long term, in the inversion of the demographic pyramid. This situation, together with the public debt in both countries, might make the future retirement pensions too low. For this reason, the concept of additional savings is promoted in both societies. The idea is that the retirement pension is payed from the compulsory contributions amassed by public insurance institutions and private insurance associations. For this puropose the Czech and Polish legislators have decided to introduce tax preferences for the taxpayers who choose additional savings.

In the Czech Republic, the taxpayer is entitled to deduct from the taxable base retirement contributions up to 24.000 Kč (923 euros) within the existing retirement system encompassing the so-called three pillars ${ }^{30}$. In addition, the taxpayer enjoys the possibility to deduct from the taxable base the retirement contribution entered into with a private insurance company based in the Czech Republic or an EU or EOG state, up to the amount of 24.000 Kč regardless of the number of agreements concluded with insurance companies. This may be put into effect provided that the payment of benefits takes place after 60 calendar months after the conclusion of the contract and the first payment takes place when the policyholder reaches the age of 60 . Further condition for the use of the preferences is that during the term of the insurance contract the taxpayer does not receive any payments related to the insurance contract. An additional condition is that the minimal amount of the insurance concluded for the period from 5 to 15 years shall be equal to $40.000 \mathrm{Kč}$

30 See more: M. Pitterling, Nezdanitelné části základu daně a položky snižující základ daně, [in:] Zdaňování př́ijmů fizckých a právnických osob 2016, (ed.) V. Dvořáková, Praha 2016, pp. 120 et seq. 
(1.538 euros), and for more than 15 years, the amount shall be equal to 70.000 Kč $\left(2.692\right.$ euros) ${ }^{31}$.

According to the Polish regulations, the taxpayer is entitled to deduct from the taxable base compulsory social contributions payed directly by this taxpayer in the tax year. The constributions include retirement, disability, sickness and accident insurance. If the taxpayer has revenue from the employment relationship, deduction applies to the contributions payed by the payer ${ }^{32}$ from the taxpayer's funds. Also, from 1 January 2012 the Polish legislator encourages taxpayers to save for the future pension. This is done by the possibility to deduct from the taxable base payments to the individual retirement security account in the tax year if the payment does not exceed 1,2 times the projected average monthly remuneration in the national economy for a given year.

Nevertheless, Polish regulations are not perfect and do not encourage the taxpayer for additional savings for the future pension as they should. Firstly, unlike in the Czech Republic, the Polish taxpayer may have only one contract for the individual retirement security account. Secondly, the amount deducted from the taxable base is very low. Thirdly, the payment of the funds collected on the individual retirement security account after reaching the retirement age is not exempted from the tax. Despite the fact that from 1 January 2014 the legislator introduced regulations on the basis of which the revenue from the payment received from the individual retirement security account is taxed with the flat-rate of $10 \%$, the taxpayers are still not encouraged enough to additional savings.

\section{FINAL REMARKS}

The comparison of the Czech Income Tax Act and the Polish Personal Income Tax Act shows that both legislators attempt to shape tax preferences so that they somplement the policies in the areas that are important from the state's point of view.

$31 \$ 15$ sec. 6 the Income Tax Act.

32 In this case, the employer is the payer. 
It has to be stressed that the geographical proximity of the two countries, similar contemporary history and common experience of economic transformation resulted in similar problems connected to, apart from the proper consideration of taxpayers' ability to pay, the demographic policy, non-profit organiations' activities, and stimulating particular behaviour among taxpayers. For this reason, tax instruments should not only be used to complement the state's pro-family policy, but also to encourage taxpayers for charity activity and saving for the future retirement. Tax intruements are also used to satisfy housing needs.

In the literature on comparative tax law, both Poland and the Czech Republic have been included into the group of transition and post-conflict countries. It has been shown that legislation in the Eastern European countries such as Poland, Hungary, Slovakia and the Czech Republic adopted such income tax solutions that can enable them to rival the OECD countries in complexity and sophistication ${ }^{33}$.

Analyses of legal arrangements concerning tax preferences in the structure of the personal income tax adopted by the Czech Republic and Poland show considerable similarities between the two countries. These similarities are due to analogous social and economical problems with which Central European countries have been struggling since 1989. One can notice that initially, legal arrangements on tax preferences were parallel. However, having diagnosed the same problems, Poland and the Czech Republic searched for different solutions. This, in turn, gave rise to dissimilar legal regulations of tax preferences.

\section{REFERENCES}

Anderlová S., 2014. Př́mé daně, [in:] Daňové právo de lege lata, (ed.) P. Jánošiková, Plzeň.

Burzec Marcin, 2013. Dziecko jako kryterium przyznania przyznania preferencji

w podatku dochodowym wybranych państw europejskich, [in:] Preferencje podatkowe, (eds.) B. Kucia-Guściora, M. Burzec, Lublin.

Litwińczuk H., 1989. Opodatkowanie rodziny, Warsaw.

33 V. Thuronyi, Comparative Tax Law..., pp. 33-38. 
Pařízková I., 2016. Slevy na dani a daňové zvýhodnění, [in] Finanční a daňové právo, (eds.) P. Jánošíková, P. Mrkývka, Plzeň.

Pelc V., 2015. Zákon o daních z př́ijmů - komentáŕ, Praha.

Pitterling M., 2016. Nezdanitelné části základu daně a položky snižující základ danĕ, [in:] Zdaňování príjmů fizckých a právnických osob 2016, (ed.) V. Dvořáková, Praha.

Samuel G., 2014. An Introduction to Comparative Law Theory and Method, Oxford and Portland.

Thuronyi V., 2003. Comparative Tax Law, The Hague-London-New York.

Wójtowicz Wanda, Smoleń Paweł, 1999. Podatek dochodowy od osób fizycznych-prorodzinny czy neutralny?, Warsaw.

Zweigert K., Kötz H., 1998. Introduction to Comparative Law, Oxford. 